\title{
MAKING NATA DE CASSAVA FROM RENGGINANG LIQUID WASTE USING ACETOBACTER XYLIUM
}

\author{
Ahmad Shobib,Ery Fatarina P Jamal Adi Prasetiyo \\ Program Studi Teknik Kimia Fakultas Teknik Universitas 17 Agustus 1945Semarang \\ Jl. Pawiyatan Luhur Bendan Dhuwur Semarang \\ E-mail:ahmadshobib@gmail.com
}

\begin{abstract}
Processed cassava liquid waste in Nyamok Village causes a decrease in water quality with a marked unpleasant odor. The liquid waste comes from the washing process of raw materials and starch deposited water containing starch. Glucose in cassava liquid waste can be a source of energy for Acetobacter Xylinum to form cellulose called nata de cassava. This study examines the potential of Rengginang UKM liquid waste as a substrate / raw material for making nata de cassava as a new material.Based on previous research, it was obtained optimization of various percentages of sugar (carbon source) and urea (nitrogen source). Therefore, this study aims to determine the optimization of the percentage of sugar and urea given in fermentation by evaluating, among others, the test water content (moisture content), tensile strength test and elongation. The study was conducted with waste preparation and processed into nata de cassava with variations of sugar and urea for 8 days of fermentation. Wet nata de cassava thickness is measured to determine the optimal recipe. The fermentation optimization results measured moisture content, dried and tested the tensile strength and elongation. The data obtained were tested statistically with two-way ANOVA. The results showed that sugar and urea are very influential in the process of bacterial cellulose formation based on anova test, namely $F>F c(11.8>2.9)$. The optimum conditions obtained are the addition of sugar 15 grams / L and urea 2 grams / L, with a thickness of $12.1 \mathrm{~mm}$. Moisture content value of $97.97 \%$, tensile strength of $14.31 \mathrm{~N} / \mathrm{mm} 2$ and elongation at $3.83 \%$.
\end{abstract}

Keyword: Nata de cassava, Urea,Sugar,Moisture content, Mensile strengt

\section{PENDAHULUAN}

Limbah cair olahan rengginang singkong di Desa Nyamok, kelurahan kajen, kabupaten pekalongan menyebabkan penurunan kualitas air dengan ditandai bau yang tidak sedap. Limbah cair tersebut berasal dari proses pencucian bahan baku dan air sisa pengendapan pati yang mengandung amilum. Glukosa dalam limbah cair singkong dapat menjadi sumber energi untuk Acetobacter Xylinum untuk membentuk selulosa yang disebut nata de cassava.

Limbah cair olahan singkong tersebut mengandung karbohidrat mencapai 2,5\%, glukosa $0,185 \mathrm{mg} / \mathrm{L}$ nitrogen total $182 \mathrm{mg} / \mathrm{L}$, dan $\mathrm{pH} 5-5,5$ sehingga dapat menjadi media hidup Acetobacter Xylinum (Badan Litbang Pertanian, 2011). Acetobacter Xylinum dapat hidup dengan optimal jika kondisi media pertumbuhannya memenuhi faktor berikut yaitu glukosa, nitrogen, kandungan oksigen terlarut, suhu dan $\mathrm{pH}$. Glukosa merupakan sumber utama dalam pembentukan selulosa yang dicerna dengan bantuan oksigen dan menghasilkan air, $\mathrm{CO}_{2}$ dan sejumlah Adenin Tri Phosphat (ATP) yang digunakan sebagaienergi untuk hidup (Winarno dalam Setyawati, 2009).

Beberapa peneliti telah membuktikan potensi limbah cair olahan singkong sebagai media fermentasi bakteri Acetobacterxylinum diantaranya Puspawiningtyas, dkk., (2013) menunjukkan pembentukan optimal nata de 
cassava dengan ketebalan $8 \mathrm{~mm}$ dengan penambahan gula pasir $10 \%$ dan $\mathrm{pH} 4$. Badan Litbang Pertanian (2011) menjelaskan.bahwa urea yang digunakan sebanyak 2 gram dengan starter bakteri $10 \% \quad(\mathrm{v} / \mathrm{v})$ dan kedalaman substrat $2 \mathrm{~cm}$ menghasilkan ketebalan nata de cassava sebesar 1,25 cm - 1,5 cm dan Nurlinda (tanpa tahun) menggunakan gula pasir $15 \%$ yang menghasilkan ketebalan nata de cassava $1,54 \mathrm{~cm}$.

Selulosa yang dibentuk oleh mikroba disebut dengan bacterial cellulose (BC), sedangkan selulosa yang menggunakan media air singkong disebut nata de cassava. Nata de cassava umumnya digunakan sebagai bahan pangan. Namun, pada penelitian ini mengkaji potensi limbah cair UKM rengginang menjadi substrat/bahan baku pembuatan nata de cassava sebagai material baru. Nata de cassavadalam bentuk kering telah diaplikasikan dalam berbagai bidang seperti industri kertas, pemurnian limbah, atau material biodegradable baru untuk makanan dan industri kimia karena kemurniannya yang tinggi, sifat kimia yang unik dan biaya yang rendah untuk produksi skala besar (Chen, 2010). Penggunaan nata de cassava sebagai material telah dilakukan untuk berbagai bidang antara lain sebagai pengganti serat sintesis di bidang tekstil (Permatasari, 2017) dan bioplastik (Animelani, dkk., 2017). Hasil penelitian ini diharapkan dapat digunakan untuk mengatasi permasalahan limbah cair rengginang sekaligus memberikan inovasi dalam bidang manufaktur yang bersifat biodegradable. Berdasarkan penelitian sebelumnya diperoleh optimasi persentase gula pasir (sumber karbon) dan urea (sumber nitrogen) yang beraneka ragam. Oleh karena itu, penelitian ini bertujuan untuk mengetahui optimasi persentase gula pasir dan urea yang diberikan dalam fermentasi agar mendapatkan ketebalan optimum dan mengkaji tentang potensi nata de cassava dalam bentuk kering sebagai material pada bidang manufaktur dengan evaluasi antara lain uji kandungan air (moisture content), uji kekuatan tarik dan kemuluran (elongation). Standar pembanding kekuatan tarik yaitu produk plastik biodegradable atau bioplastik karena memiliki persamaan bahan baku yang berasal dari alam berupa pati dan merupakan salah satu polimer alami dari ekstraksi tanaman (Animelani, dkk., 2017). Berdasarkan hal tersebut, peneliti meneliti tentang kondisi optimum penambahan gula pasir dan urea pada pembentukan nata de cassava menggunakan acetobacter xylinum dan limbah cair UKM rengginang singkong.

\section{METODOLOGI}

Metode yang dipakai adalah anova dua sisi. Metode penelitian ini dipilih karena variabel bebas/berubah dipilih menjadi dua, yaitu variabel gula dan variabel urea. Metode ini digunakan untuk mengetahui pengaruh persentase gula pasir dan urea dalam proses fermentasi pembuatan Nata de Cassava dengan kedalaman substrat $1.5 \mathrm{~cm}$ dan waktu inkubasi 8 hari.

\section{Penyiapan Substrat Cair}

Substrat yang digunakan untuk starter bakteri adalah air kelapa dan substrat nata de cassava berupa limbah cair rengginang yang dipisahkan dari kotoran yang ada didalamnya. Penyaringan dilakukan agar terhindar dari kotoran yang berasal dari proses sebelumnya. Limbah cair tersebut sebelumnya telah dilakukan pengecekan kadar gulanya yaitu sebesar $0,523 \% \mathrm{~b} / \mathrm{b}$ yang dilakukan di Balai Besar Pencegahan Pencemaran Industri Semarang.

\section{Pengembang Biakan Starter Bakteri}

Satu liter air kelapa yang telah disaring kemudian ditambahkan dengan $3 \mathrm{gr} / \mathrm{L}$ pupuk Urea $\left(\mathrm{CH}_{4} \mathrm{~N}_{2} \mathrm{O}\right)$ dan 6 gr/L gula pasir. Campuran diaduk hingga homogen kemudian direbus hingga mendidih. Setelah mendidih, api dikecilkan dan dilakukan pengecekan $\mathrm{pH}$ sekitar 3-4. Larutan yang telah berada dalam rentang $\mathrm{pH}$ tersebut, diisikan ke dalam botol berukuran $250 \mathrm{~mL}$ yang sudah disterilkan. Sebaliknya jika larutan belum mencapai $\mathrm{pH}$ 3- 
4 api dimatikan dan ditambahkan $\mathrm{CH}_{3} \mathrm{COOH}$ sampai mencapai $\mathrm{pH}$ tersebut. Selanjutnya, campuran air kelapa ditempatkan dalam botolbotol yang telah disiapkan sambil ditutup dengan kertas koran dan diikat. Sterilisasi botol dengan cara dimasukkan dalam air mendidihselama \pm 15 menit. Penambahan starter bakteri Acetobacter xylinum dilakukan saat larutan dalam keadaan dingin dan diberikan sebanyak $25 \mathrm{ml}$ atau 10\%.Peremajaan starter bakteri Acetobacter xylinum dibiarkan selama 7 hari agar terjadi proses fermentasi (Salim, 2012).

\section{Pembuatan Nata de Cassava}

Limbah cair yang telah disaring kemudian di rebus sampai mendidih kemudian ditambah gula pasir dengan variasi sesuai variabel $(0,5$, 10, 15, dan 20) gram setiap 1liter dan urea sesuai variabel $(0,1,2$, dan 3$)$ gram setiap 1 liter. Perebusan dilakukan hingga mencapai $100^{\circ} \mathrm{C}$ selama 10 menit. Kondisi keasaman larutan $\mathrm{pH} 4$ dicek dengan $\mathrm{pH}$ universal. Setelah mendidih, dilakukan penyaringan untuk mendapatkan sari hasil rebusan kemudian direbus kembali dengan suhu $100^{\circ} \mathrm{C}$ selama 10 menit selanjutnya setelah perebusan dituangkan dalam nampan plastik dan ditutup dengan koran yang telah disterilkan sebelumnya dengan dijemur dan disetrika kemudian diikat dengan karet. Substrat didiamkan hingga dingin kemudian ditambahkan starter bakteri sekitar 100 $\mathrm{mL} / \mathrm{liter}$ atau $10 \%(\mathrm{v} / \mathrm{v})$ limbah. Proses fermentasi berlangsung 8 hari. Dari beberapa sampel dipilih hasil yang optimum dari varaisi penambahan gula pasir dan urea berdasarkan hasil ketabalan nata yang dihasilkan. Selanjutnya hasil tersebut digunakan sebagai resep pembuatan nata de cassava yang akan dipakai dalam proses pengujian moisture content, kekuatan tarik, dan elongation.

\section{Preparasi Sampel Uji Laboratorium}

Nata de cassava yang didapatkan dibersihkan dari sisa-sisa bakteri dan pengotor lainya dengan cara dicuci dengan air. Lembaran selulosa yang masih basah diukur ketebalan dan kadar airnya. Pengukuran ketebalan menggunakan jangka sorong. Langkah selanjutnya yaitu mengeringkan lembaran Nata de Cassava dengan cara pemanasan dibawah sinar matahari secara langsung berdasarkan penelitian Quijano(2017) yang dianalisa berdasarkan berat konstan setelah pengeringan.

\section{Teknik Pengambilan Data dan Analisis Data}

Teknik pengambilan data dilakukan dengan melakukan pengujian sebanyak dua kali skala laboratorium dan diujikan di lembaga pengujian yang telah terakreditasi. Kandungan air, dan tebal sampel dilakukan manual dengan skala laboratorium. Analisis data selulosa bakterial dari limbah cair rengginang singkong di ukur ketebalan, moisture content, kekuatan tarik, dan kemuluran. Analisis data dan uji mutu yang dilakukan untuk mengetahui potensi selulosa bakterial dari limbah cair rengginang singkong sebagai material.

\section{HASIL DAN PEMBAHASAN}

Proses fermentasi limbah cair ukm rengginang singkong pada hari ke-2, lembaranNata de Cassava telah terbentuk lapisan tipis dan transparan. Fermentasi dihentikan pada hari ke-8, dengan penampakan fisik putih keruh, licin dan berbau asam. lembaranNata de Cassava yang sempurna dapat terlihat dengan sedikit atau tidak ada medium yang tersisa pada nampan, permukaan rata, tidak berlubang, berwarna putih dan beraroma asam. Namun hasil fermentasi ini dapat mengalami kendala dan kegagalan akibat kontaminan, goncangan, kualitas bakteri, dan kandungan nutrisi media. Kendala tersebut yang mempengaruhi kualitas dari lembaranNata de Cassava seperti ketebalan dan warna.Fermentasi digunakan untuk memproduksi Nata de Cassava sebagai material edible film.

Pada peremajaan bakteri, air kelapa digunakan sebagai substrat karena mengandung banyak mineral antara lain gula, protein, vitamin 
sehingga memaksimalkan bakteri untuk hidup dan berkembang biak membentuk Nata de Cassava. Sedangkan limbah perasan singkong digunakan sebagai substrat alternatif pembentukan lembaranNata de Cassavasehingga adanya inovasi substitusi air kelapa dan solusi penanganan polusi lingkungan.

Kondisi medium fermentasi yaitu limbah perasan singkong diatur pada $\mathrm{pH} 4$ atau 5 , dengan penambahan gula pasir sebesar $5,1 \%$ w/vserta inkubasi selama 7-8 hari berdasarkan penelitian Afreen (2014). Pembentukan selulosa terjadi 24 jam setelah inkubasi dan meningkat dengan cepat setelah 4 hari inkubasi, kemudian cenderung lambat pada hari selanjutnya. Hal ini dikarenakan keasaman medium bertambah serta gula dalam substrat telah berkurang (Alaban dalam Arviyanti, 2009).Nata de Cassava dalam membentuk polisakarida melepaskan gas $\mathrm{CO}_{2}$ yang terhambat dan menempel pada mikro fibril selulosa sehingga naik kepermukaan medium. Oleh karena itu, lapisan lembaran Nata de Cassava yang terbentuk secara perlahan menutupi permukaan media pada suhu ruang.

Penambahan gula pasir dan urea merupakan salah satu faktor yang mempengaruhi proses fermentasi pembentukan selulosa bakterial oleh bakteri acetobacter xylinum. Optimasi penambahan gula pasir dan urea bertujuan untuk mengetahui jumlah gula pasir dan urea maksimum yang di perlukan oleh bakeri acetobacter xylinum dalam pembentukan selulosa bakterial yang diukur berdasarkan ketebalan. Dalam prosesnya bakteri akan mengoksidasi gula pasir (sumber karbon) menjadi produk akhir selulosa dan asam asetat. Sedangkan urea ditambahkan sebagai suplemen makanan (sumber nitrogen dan sulfur dalam proses metabolisme) bagi bakteri acetobacter xylinum, untuk meningkatkan produktifitasnya dalam mengubah gula dalam air limbah menjadi serat selulosa. Pada penelitian ini variasi gula pasir yang diberikan yaitu $(0,5,10,15$, dan 20$)$ gram/L dan variasi urea $(0,1$, 2.dan 3) gram/L. Variabel $0 \mathrm{~g} / \mathrm{L}$ gula pasir dan $0 \mathrm{~g} / \mathrm{L}$ urea digunakan sebagai standar. Hasil pengamatan dapat dilihat pada grafik.

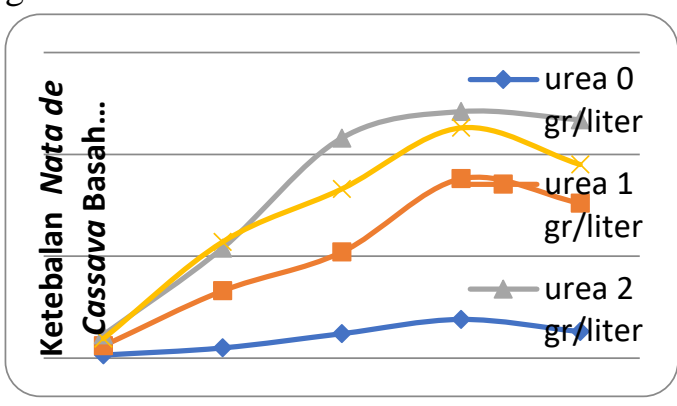

Gula yang terkandung dalam limbah cair perasan singkong digunakan sebagai sumber karbon atau penyedia energi untuk bakteri tersebut. Kandungan sukrosa didalam gula pasir berfungsi sebagai sumber karbon yang dibutuhkan untuk pertumbuhan bakteri. Selama proses fermentasi berlangsung ketebalan lembaran Nata de Cassava mengalami peningkatan. Perbedaan perlakuan mengakibatkan ketebalan lembaran Nata de Cassava berbeda dengan ketebalan tertinggi pada konsentrasi gula pasir $15 \mathrm{~g} / \mathrm{L}$ dan urea 2 $\mathrm{g} / \mathrm{L}$, dengan ketebalan nata de cassava basah 12,1 mm, Pada konsentrasi $15 \mathrm{~g} / \mathrm{L}$ gula pasir menghasilkan ketebalan Nata de Cassava tertinggi menunjukkan bahwa kondisi tersebut merupakan kondisi optimal bakteri membentuk selulosa. Meskipun pada konsentrasi $20 \mathrm{~g} / \mathrm{L}$ memiliki penurunan ketebalan Nata de Cassava dengan selisih yang kecil disebabkan oleh konsentrasi gula pasir yang terlalu tinggi sehingga mengganggu metabolisme bakteri. Menurut Atih dalam Novianti (2003), penambahan gula pasir yang terlalu banyak kurang menguntungkan karena akan berpengaruh terhadap aktivitas bakteri, mengakibatkan penurunan $\mathrm{pH}$ fermentasi akibat pengubahan gula pasir menjadi asam. Penambahan gula pasir yang terlalu tinggi menyebabkan terjadinya plasmolisis (dehidrasi) dalam sel bakteri, sehingga menurunkan pembentukan selulosa (Iskandar, dkk., 2010).

. Nilai moisture content nata de cassava basah rata - rata 97,97\%. Berdasarkan Rubelo, dkk., 
(2018) pengeringan Nata de Cassavayang mencapai MC sekitar $98 \%$ menunjukkan proses dehidrasi yang sempurna. Struktur molekul pada Nata de Cassava memiliki air terikat dan air bebas, sehingga dengan persentase tersebut seluruh molekul air yang terikat secara ikatan heterogen dapat terlepas. Persentase MC pada Nata de Cassavakering akan mempengaruhi sifat yang disesuaikan denagan end product. Kandungan air yang tinggi akan menurunkan kekuatan material, dan sifat elektrokimia.

Kekuatan tarik adalah tegangan maksimum yang bisa ditahan oleh sebuah bahan ketika diregangkan atau ditarik, sebelum bahan tersebut patah. Pengujian kekuatan tarik sangat dibutuhkan dalam pengujian bioplastik atau material lain karena dalam proses pembuatan produk maupun pemakaiannya, material mengalami penarikan maupun renggangan.

Pada kondisi optimum (gula pasir $15 \mathrm{~g} / \mathrm{L}$ dan urea $2 \mathrm{~g} / \mathrm{L}$ ) yang didapatkan, dihasilkan kekuatan tarik rata-rata sebesar $14,31 \mathrm{~N} / \mathrm{mm}^{2}$. Material selulosa yang dihasilkan memiliki kekuatan tarik cukup tinggi akibat konsentrasi gula dalam medium yang tinggi sehingga mengakibatkan kandungan serat meningkat. Kekuatan tarik dan elongation Nata de Cassava kering sebesar 14,31 N/mm² dan 3,83 $\%$ menunjukkan bahwa material selulosa ini masih jauh dengan standar plastik menurut SNI yaitu kekuatan tarik plastik sebesar 24,7-302 $\left(\mathrm{N} / \mathrm{mm}^{2}\right)$ dan elongation 21-220 (\%) (Ani, 2017).

\section{KESIMPULAN}

Hasil penelitian dapat disimpulkan gula pasir dan urea sangat berpengaruh dalam proses pembentukan selulosa bakterial berdasarkan uji anova yaitu $\mathrm{F}>\mathrm{Fc} \quad(11.8>2,9)$ Kondisi optimum yang diperoleh adalah pada penambahan gula pasir $15 \mathrm{gram} / \mathrm{L}$ dan urea 2 gram/L, dengan ketebalan nata de cassava basah 12,1 mm. Nilai moisture contentnata de cassava basah sebesar 97,97\%, kekuatan tarik sebesar $14,31 \mathrm{~N} / \mathrm{mm}^{2}$ dan perpanjangan putus $3,83 \%$.

\section{DAFTAR PUSTAKA}

Afreen \& Lokeshappa. 2014. Production of Nata de Cassava From Acetobacter Xylinum Using Fruits Wastes As Substrate. Vol 2 Issue 8:The International Journal of Science \&Technoledge.

Badan Litbang Pertanian 2011.”Pemanfaatan Limbah Cair Produksi Pati Kassava Sebagai Substrat Pembuatan Nata De Cassava" edisi 18-24

Chen,Peng, dkk,. 2010. Modification and application of Nata de Cassavas in polymer science. Vol 18, No 4:Springer.

Effendi,N.H.2009.Pengaruh Penambahan Variasi Massa Pati (Soluble Strach) Pada Pembuatan Nata De Coco Dalam Medium Fermentasi Bakteri Acetobacter Xylinum. Skripsi, Fakultas Matematika dan Ilmu Pengetahuan Alam: Universitas Sumatera Utara.

Iskandar, dkk., 2010. Pembuatan Film Selulosa dari Nata de Pina. Jurnal Rekayasa Kimia dan Lingkungan. 7(3): 105-111

Mayasti, Nur Kartika \& Ari, Darmawan. 2013. Pemanfaatan Ampas Basah Tapioka Sebagai Media Fermentasi dalam Pembuatan Nata de Cassava. Balai Besar Pengembangan Teknologi Tepat Guna:LIPI.

Mohammad, S. M, et al. 2014. "An Overview of Biocellulose Production Using Acetobacter Xylinum Culture". Biological research 8 (6):307-313.

Novianti dan Hendrizon.2003. Pembuatan Nata de Soya dari Limbah Cair Pabrik Tahu. Jurnal Teknik Kimia. 9-19 
Nurlinda, dkk. Tanpa Tahun. Efektivitas Penambahan Gula Terhadap Kualitas Nata de Cassava Dari Limbah Cair Tapioka Sebagai Pengembangan Modul Pada Konsep Bioteknologi Konvensional Kelas XII SMA. Skripsi: Universitas Riau

Permatasari., Amaliya Sita, Winaningsih., Ima, \& Saputro, Budi. 2017. "Potensi Bakteri Acetobakter Xylinum Sebagai Bahan Tekstil Ramah Lingkungan (Ecotextile)". Politeknik Negeri Bandung.

Puspawiningtyas, Endar \& Ma'ruf, Anwar. 2013. "Kajian Awal Pemanfaatan Limbah Tepung Tapioka Sebagai Substrat Pembuat Nata". Techno, ISSN 1410-8607, Vol. 14, No.2, Hal. 42-52.

Rubelo., Ana, dkk,. 2018. Dehydration Of Nata de Cassava And the Water Content Effects On Its Viscoelastic And Electrochemical Properties. Science And Technology Of Advanced Materials, Vol 19 no 1, 203-211

Salim, Emil. 2012. "Sukses Bisnis Nata De Cassava Skala Rumah Tangga”. Yogyakarta: Lily Publisher. 